\title{
Restoration by xanthine of development of mouse embryos inhibited by mycophenolic acid
}

\author{
M. Hoshi, A. Mizuno and A. Yuki \\ Research Institute of Life Science, Snow Brand Milk Products Co., Ltd, Shimoishibashi, \\ Ishibashi-machi, Shimotsuga-gun, Tochigi, 329-05 Japan
}

\begin{abstract}
Summary. Mouse embryos at the 1-cell stage were cultured in various concentrations of mycophenolic acid and xanthine. Mycophenolic acid at 10 and $2.5 \mu \mathrm{g} / \mathrm{ml}$ completely inhibited development to the morula and blastocyst stages, respectively. The addition of xanthine reversed the inhibitory effects of mycophenolic acid on the embryos but the reversal effect depended on the concentration of xanthine. Development was normal with a xanthine concentration of $25 \mu \mathrm{g} / \mathrm{ml}$, even when an inhibitory concentration of mycophenolic acid was present. Embryo transfer experiments showed that the blastocysts formed in vitro in the presence of mycophenolic acid + xanthine could implant in foster mothers and develop normally to fetuses.
\end{abstract}

Keywords: mouse embryos; mycophenolic acid; xanthine

\section{Introduction}

Culturing mammalian embryos in the presence of metabolic inhibitors provides information concerning the mechanisms that control early events of development. Mycophenolic acid, an inhibitor of purine nucleotide synthesis (Franklin \& Cook, 1969), has been used to study mouse oocyte maturation in vivo (Downs \& Eppig, 1987) and preimplantation embryo development in vitro (Hoshi \& Yuki, 1986). The results reported in these papers showed that the effects of mycophenolic acid are unique when compared to other inhibitors, such as actinomycin D (Monesi et al., 1970; Golbus et al., 1973), $\alpha$-amanitin (Levey et al., 1977; Bolton et al., 1984) and puromycin (Monesi et al., 1970).

Hoshi \& Yuki (1986) have shown that mouse preimplantation embryos were apparently different from other mammalian cells in terms of their sensitivity to mycophenolic acid: the development of the embryos before compaction was not inhibited at all by mycophenolic acid at a concentration of $50 \mu \mathrm{g} / \mathrm{ml}$.

In this study, the effects of mycophenolic acid on development of mouse embryos beyond the compaction stage were examined. The effect of xanthine on development of the embryos in the presence of mycophenolic acid was also examined to show the mode of action of mycophenolic acid on embryos.

\section{Materials and Methods}

\footnotetext{
Embryos at the 1-cell stage were collected from female B6C3F, mice (C57BL/6 $\times \mathrm{C} 3 \mathrm{H} / \mathrm{He}$, Charles River Japan Inc., Tokyo, Japan) and cultured as described previously (Hoshi \& Yuki, 1986). The females, 7-9 weeks of age, were superovulated by PMSG and hCG injections and then mated with CD-1 males (Charles River Japan).

The embryos were recovered from several females at $20 \mathrm{~h}$ after the hCG injection and they were pooled. Cumulus cells around the embryos were removed by treatment with $1 \mathrm{mg}$ hyaluronidase/ml (Sigma Chemical Co., St Louis, MO, U.S.A.) for 5-10 min at room temperature. All the culture experiments were done in $50 \mu \mathrm{l}$ of Whitten's medium
} 
(Whitten, 1971) covered with paraffin oil (Wako Pure Chemical Industries, Ltd, Osaka, Japan). The culture dishes were maintained at $37^{\circ} \mathrm{C}$ in an atmosphere of $5 \% \mathrm{CO}_{2}$ in air at saturation humidity.

Mycophenolic acid (Sigma) and xanthine (Sigma) were dissolved in $0 \cdot 1 \mathrm{~N}-\mathrm{NaOH}$. Both or one of these stock solutions (mycophenolic acid, $500 \mu \mathrm{g} / \mathrm{ml}$; xanthine, $5 \mathrm{mg} / \mathrm{ml}$ ) were added to a concentrated Whitten's medium containing reduced concentration of $\mathrm{NaCl}$. $\mathrm{HCl}(0 \cdot 1 \mathrm{~N})$ was then added to neutralize the mixture. The concentration of $\mathrm{NaCl}$ in the medium was adjusted by adding $50 \mathrm{~mm}-\mathrm{NaCl}$ to give a final concentration of $88 \mathrm{~mm}$. The medium thus made was sterilized by filtration through a Millipore filter (Millex-GS, pore size 0.22 $\mathrm{mm}$; Millipore Co., Bedford, MA, U.S.A.) just before use.

In each culture 12 embryos were incubated in the continuous presence of mycophenolic acid or xanthine or both, and examined under an inverted microscope. The stages of development were determined as described by Biggers et al. (197I).

Some of the blastocysts formed in the presence of xanthine + mycophenolic acid were transferred to the uterine horns of CD-1 females made pseudopregnant by mating with vasectomized males. The recipients were killed on the 14 th day after blastocyst transfer and examined for implantation sites and fetuses.

\section{Results}

Figure 1 shows the effects of various concentrations of mycophenolic acid on the development of 1-cell mouse embryos. As reported earlier (Hoshi \& Yuki, 1986), development before the morula stage was not inhibited at all. However, development to the morula or early blastocyst stage was fully inhibited with $10 \mu \mathrm{g}$ mycophenolic acid/ml (Fig. 1). Late blastocyst formation was more sensitive and was completely inhibited with $2.5 \mu \mathrm{g}$ mycophenolic acid/ml (Fig. 1).

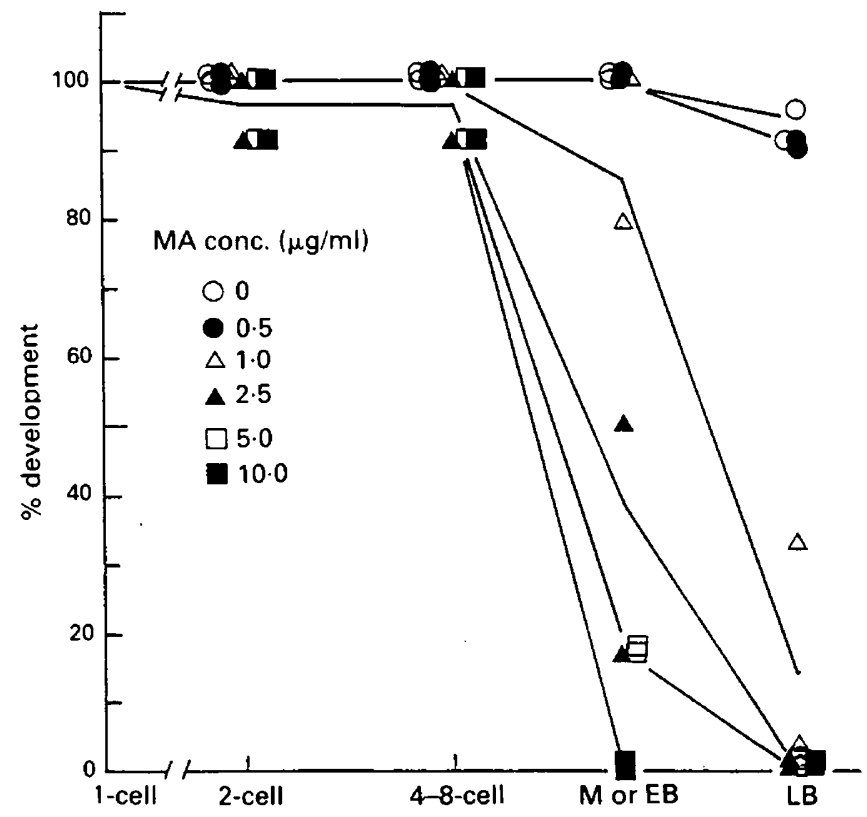

Fig. 1. Effect of mycophenolic acid (MA) on development of 1-cell mouse embryos in vitro. The results of two separate experiments are shown: 12 or 24 embryos were used for each concentration of mycophenolic acid. $\mathbf{M}=$ morula; $\mathrm{EB}=$ early blastocyst; $\mathbf{L B}=$ late blastocyst.

The effect of xanthine on development to the morula or early blastocyst stage was tested by adding various amounts of xanthine to the cultures containing $10 \mu \mathrm{g}$ mycophenolic acid $/ \mathrm{ml}$. The addition of xanthine reversed the inhibition depending on the concentration of xanthine (Fig. 2a). At a concentration of $25 \mu \mathrm{g} / \mathrm{ml}$, development was similar to that when no mycophenolic acid was added (Fig. 2a); no significant differences between these two were observed $\left(\chi^{2}=0.63, P>0.05\right)$. 


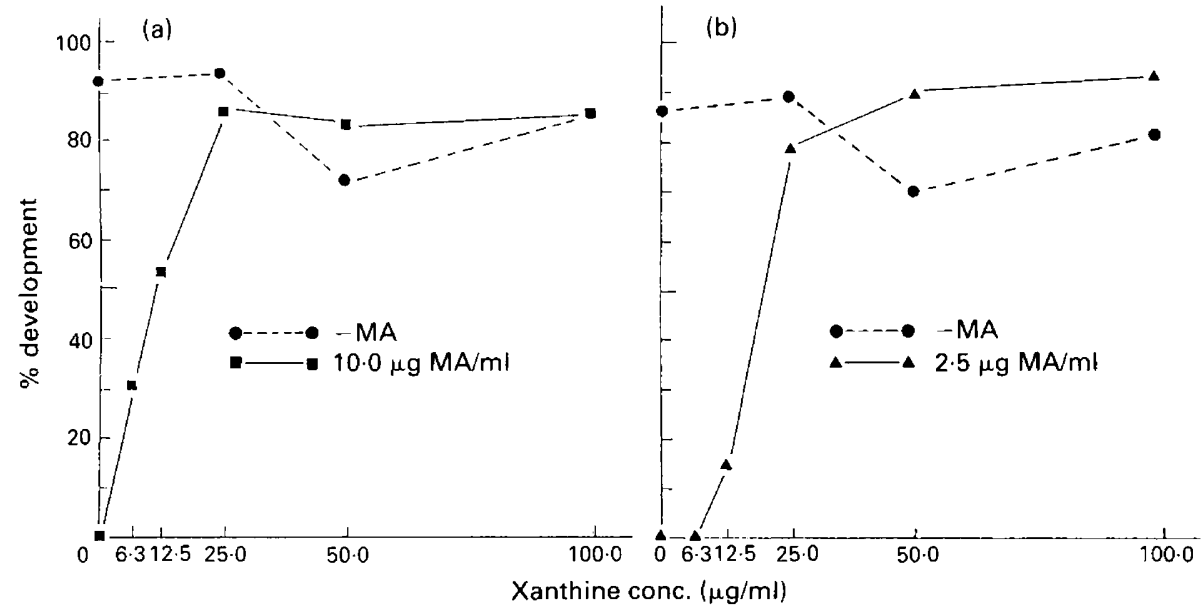

Fig. 2. Effect of xanthine on the development of 1-cell mouse embryos to (a) morulae or early blastocysts and (b) late blastocysts in the presence of mycophenolic acid (MA) at (a) $10 \mu \mathrm{g} / \mathrm{ml}$ and (b) $2.5 \mu \mathrm{g} / \mathrm{ml}$. Total number of embryos used for each point was 36 .

When medium containing $2.5 \mu \mathrm{g}$ mycophenolic acid/ml was used, the formation of late blastocysts was fully restored by adding $25 \mu \mathrm{g}$ xanthine $/ \mathrm{ml}$. However, a minimum of $6.3 \mu \mathrm{g}$ xanthine $/ \mathrm{ml}$ was required to show even partial recovery (Fig. 2b). Xanthine itself did not show any effect up to $100 \mu \mathrm{g} / \mathrm{ml}$ on formation of morulae (Fig. 2a) or late blastocysts (Fig. 2b).

No differences were observed under the microscope between the late blastocysts formed in the absence of mycophenolic acid (Fig. 3a) and those developed in the presence of mycophenolic acid + xanthine (Fig. 3c), while embryos degenerated in the presence of mycophenolic acid alone (Fig. 3b).
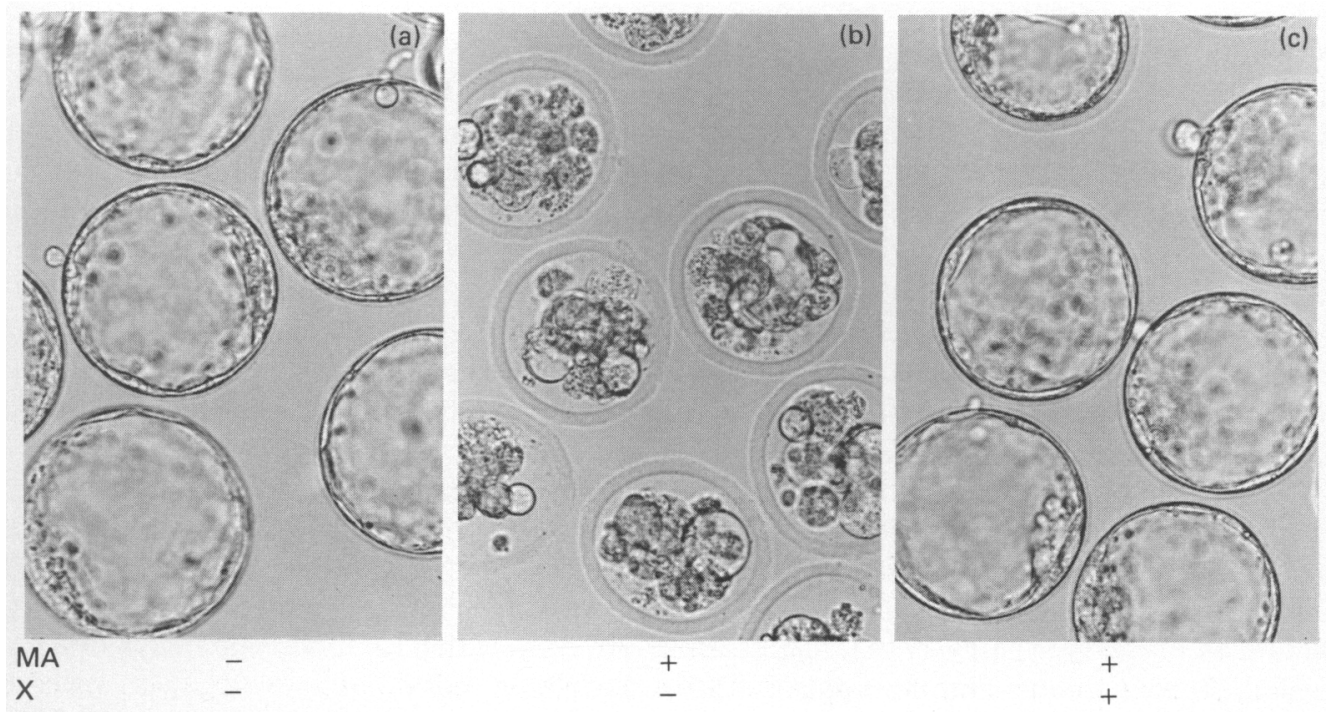

Fig. 3. Development of 1-cell mouse embryos cultured for $96 \mathrm{~h}$ in (a) Whitten's medium; (b) Whitten's medium containing $2.5 \mu \mathrm{g}$ mycophenolic acid $/ \mathrm{ml}$; and (c) Whitten's medium containing $2.5 \mu \mathrm{g}$ mycophenolic $\mathrm{acid} / \mathrm{ml}+100 \mu \mathrm{g}$ xanthine $/ \mathrm{ml}$. MA $=$ mycophenolic acid; $\mathrm{X}=$ xanthine. 
The results of transfers of embryos formed in the presence of mycophenolic acid + xanthine to uteri of pseudopregnant mice are shown in Table 1.

Table 1. Development of 1-cell mouse embryos cultured for $96 \mathrm{~h}$ in the absence and presence of $2.5 \mu \mathrm{g}$ mycophenolic acid $/ \mathrm{ml}+100 \mu \mathrm{g}$ xanthine $/ \mathrm{ml}$ and transferred to uteri of pseudopregnant mice

\begin{tabular}{|c|c|c|c|c|c|c|}
\hline $\begin{array}{l}\text { Mycophenolic } \\
\text { acid }\end{array}$ & Xanthine & Recipient & & $\begin{array}{l}\text { No. }(\%) \text { of } \\
\text { embryos } \\
\text { transferred* }\end{array}$ & $\begin{array}{c}\text { No. }(\%) \text { of } \\
\text { implantation } \\
\text { sites } \dagger\end{array}$ & $\begin{array}{c}\text { No. }(\%) \\
\text { of live } \\
\text { fetuses } \dagger\end{array}$ \\
\hline \multirow[t]{5}{*}{-} & - & 1 & & 18 & 13 & 5 \\
\hline & & 2 & & 16 & 9 & 1 \\
\hline & & 3 & & 16 & 12 & 11 \\
\hline & & 4 & & 16 & 9 & 7 \\
\hline & & & Total & $66(100)$ & $43(65 \cdot 2)$ & $24(36 \cdot 4)$ \\
\hline \multirow[t]{5}{*}{+} & + & 1 & & 15 & 9 & 3 \\
\hline & & 2 & & 15 & 15 & 11 \\
\hline & & 3 & & 16 & 12 & 8 \\
\hline & & 4 & & 16 & 15 & 11 \\
\hline & & & Total & $62(100)$ & $51(82 \cdot 3)$ & $33(53 \cdot 2)$ \\
\hline
\end{tabular}

${ }^{*}$ Only blastocysts were transferred to recipients.

$\dagger$ The recipients were killed on the 14th day after embryo transfer.

\section{Discussion}

Mycophenolic acid inhibits inosine monophosphate dehydrogenase, and thus inhibits DNA synthesis of mammalian cells in the absence of guanine (Franklin \& Cook, 1969). A gram-negative bacterium, Escherichia coli, has an enzyme named xanthine-guanine phosphoribosyltransferase (XGPRT) which converts xanthine to XMP efficiently (Miller et al., 1972). An analogous mammalian enzyme, hypoxanthine phosphoribosyltransferase (HPRT), utilizes xanthine but only poorly (Krenitsky et al., 1969). Therefore, the bacterium can grow in the presence of mycophenolic acid and the absence of guanine, if enough xanthine is added to the medium. However, growth of mammalian cells, such as mouse L cells (Franklin \& Cook, 1969) and human fibroblasts (Mulligan \& Berg, 1981; Chu \& Berg, 1985), cannot be reversed by addition of xanthine in the presence of mycophenolic acid.

Our results presented here showed that the mouse embryos at the morula and blastocyst stages were sensitive to mycophenolic acid. However, unlike the effect on other mammalian cells described above, xanthine detoxicated the inhibitory effects of mycophenolic acid during formation of the morula and blastocyst stages.

The effect of xanthine reported here cannot be explained by a chemical inactivation of mycophenolic acid with xanthine, because mycophenolic acid inhibits growth of mouse $L$ cells and other animal cells in the presence of xanthine (Franklin \& Cook, 1969; Mulligan \& Berg, 1981; Chu \& Berg, 1985). A simple explanation of the results is that the mouse preimplantation embryos contain an $E$. coli-type pathway to utilize xanthine. An enzyme that catalyses xanthine to GMP has been obtained in human fibroblast cells, XP20S (Chu \& Berg, 1985).

Although further analysis is necessary, it is possible that mammalian cells have a gene to code for the enzyme, and the gene is expressed at the preimplantation embryo stage and suppressed as they develop. The case of XP20S cells might be explained by an abnormality of regulation of gene expression. 


\section{References}

Biggers, J.D., Whitten, W.K. \& Whittingham, D.G. (1971) The culture of mouse embryos in vitro. In Methods in Mammalian Embryology, pp. 86-116. Ed. J. C. Daniel, Jr. Freeman, San Francisco.

Bolton, V.N., Oades, P.J. \& Johnson, M.H. (1984) The relationship between cleavage, DNA replication, and gene expression in the mouse 2-cell embryo. $J$. Embryol. exp. Morph. 79, 139-163.

Chu, G. \& Berg, P. (1985) Rapid assay for detection of Escherichia coli xanthine-guanine phosphoribosyltransferase activity in transduced cells. Nucleic Acid Res. 13, 2921-2930.

Downs, S.M. \& Eppig, J.T. (1987) Induction of mouse oocyte maturation in vivo by perturbants of purine metabolism. Biol. Reprod. 36, 431-437.

Franklin, T.J. \& Cook, J.M. (1969) The inhibition of nucleic acid synthesis by mycophenolic acid. Biochem. J. 113, 515-524.

Golbus, M.S., Calarco, P.G. \& Epstein, C.J. (1973) The effects of inhibitors of RNA synthesis ( $\alpha$-amanitin and actinomycin D) on preimplantation mouse embryogenesis. J. exp. Zool. 186, 207-216.

Hoshi, M. \& Yuki, A. (1986). Effect of mycophenolic acid on development of preimplantation mouse embryos in vitro. Jpn. J. Anim. Reprod. 32, 147-152.
Krenitsky, T.A., Papaioannou, R. \& Elion, G.B. (1969) Human hypoxanthine phosphoribosyltransferase. I. Purification, properties, and specificity. J. biol. Chem. 244, 1263-1270.

Levey, I.L., Troike, D.E. \& Brinster, R.L. (1977) Effects of $\alpha$-amanitin on the development of mouse ova in culture. J. Reprod. Fert. 50, 147-150.

Miller, R.L., Ramsey, G.A., Krenitsky, T.A. \& Elion G.B. (1972) Guanine phosphoribosyltransferase from Escherichia coli, specificity and properties. Biochemistry N.Y. 11, 4723-4731.

Monesi, V., Molinaro, M., Spolletta, E. \& Davoli, C. (1970) Effect of metabolic inhibitors on macromolecular synthesis and early development in the mouse embryo. Expl Cell Res. 59, 197-206.

Mulligan, R.C. \& Berg, P. (1981) Selection for animal cells that express the Escherichia coli gene coding for xanthine-guanine phosphoribosyltransferase. Proc. natn. Acad. Sci. U.S.A. 78, 2072-2076.

Whitten, W.K. (1971) Nutrient requirements for the culture of preimplantation embryos in vitro. Adv. Biosci. 6, 129-141.

Received 9 June 1987 